\title{
Several Unfavorable Estimates on African Americans Implicate Poverty: Need for More Understanding and Participating in the Market Economy
}

\author{
Amaechi N. Nwaokoro ${ }^{1}$, Victor Williams ${ }^{1} \&$ Sandra Washington ${ }^{1}$ \\ ${ }^{1}$ College of Business, Education and Professional Studies, USA \\ Correspondence: Amaechi N. Nwaokoro, Ph.D., Professor of Economics, College of Business, Education and \\ Professional Studies, 504 College Drive Albany, George 31705, United States. Tel: 1-229-500-2132. E-mail: \\ Amaechi.nwaokoro@asurams.edu
}

Received: October 7, 2020

Accepted: November 27, 2020

Online Published: August 10, 2021

doi:10.5539/ijef.v13n9p84

URL: https://doi.org/10.5539/ijef.v13n9p84

\begin{abstract}
This empirical study references estimates of the critical economic misery indices such as unemployment, incarceration, poverty purchasing power disparity to present the stunted economic status of African American in the contemporary free market economy. Most especially, the estimates of the unemployment present that African American is in an economic depression when the white is in an economic recession. These estimates have led a disproportional purchasing power disparity faced by the group. The study encourages elevated market entrepreneurship, business partnership, and education to minimize the misery economic indices.
\end{abstract}

Keywords: inequality, disparity-estimates, mass-incarceration, discrimination, poverty, entrepreneurship, unemployment

\section{Introduction}

African Americans are characterized by several economic disparity indices that tend to particularly emanate from economic perspectives. The disparities tend to interact and could adversely affect the market understanding of earning a profit. Some may not understand a market economy as the one in which all economic resources are distributed by the central roles of the prices in the different markets making up the market economy. These price systems or mechanisms need to be understood by African American to have effective market engagements. Understanding a competitive market-based economy leads to the identification of the specific factors that could be engaged to have successful market operations and planning. Inability to understand a competitive economy would inhibit the capability endowment of the human capital and therefore of market initiatives and engagements for earning a profit, and for personal and community development.

The outcomes of a latent or an inhibited human endowment could be a perpetuation of personal and communal poverty (vicious cycle of poverty). An enlarged poverty state would among other things lead to large underdevelopment and incarceration, inhibited incomes, and pronounced criminal and hedonic activities. An enlarged-poverty environment would most likely deprive people of the basic human rights and freedom. This situation would tend to have a highly limited individuals' participation in democracy. Treating poverty outside of the market only by having the institutional programs for transferring various entitlements to individuals would most likely lead to enduring and positively trending poverty and misery. Those trapped in this abject poverty situation may not have the independent initiatives to rise out of the entrapment.

A critical condition needs a critical remedy. Therefore, and since America strongly believes in a private property-based economy, a critical poverty intervention that intends to minimize the long-term economic misery indices, will need to have market introduction as a major component. Like functional education, a resource-distributive market is an equalizer instrument that brings out people's endowment to have a favorable market scales of operations, and income. There is no gain saying that the average income from a market arena would be substantially greater than that from a hedonic activity or a non-market space. The articulation of market functionality and attributes would most likely expand the African American market's horizon of operations and planning. There is no gain saying that people can improve their economic learning curves by having relationships with those that express pragmatic market attributes and engagements. Market and its attributes may 
as well be preached to African American to solicit their understanding for minimizing the disparity indices.

Even in Dougherty County, Georgia, in which African American constitutes the majority, the level of the county's economic performance is substantially limited. This dualistic, agrarian, and restricted county has the white in the west and north of the county while African American is mostly located in the east and south of the county. Most of the few big businesses, and the retail, financial, and service businesses are in the north and west of the county where the white is located. Even the scattered small businesses in the African American communities are mostly owned by the white and new immigrants. These entrepreneurs express the limited entrepreneurship in these communities since there is a highly limited African American indigenous entrepreneurs in the communities. Instead, African American leadership efforts are mostly in the faith-based and nonprofit organizations, in health and educational services.

A non-market comprehension could lead to self-selections of crimes and of hedonic activities that may be punished with heavy, mass, and disproportional incarceration of African American. African American labor discrimination would interact with other adverse indices to magnify the levels of the: incarceration, unemployment, child pregnancy, and poverty. Generally, and unless there is a developed strong potential to excel in the market, a conviction record would diminish the potential of the human capital to earn according to the dictates of productivity. Economic indices estimates on the average weekly earnings, unemployment, and poverty would highlight the unfavorably stunted economic performances from an environment with even African American majority (Nwaokoro, Marshall, \& Mittal, 2013).

Due to a long period of being excluded from the price economy or of being latently accommodated in it, or due to the culture of liberal entitlements, African American is yet to comprehend strongly the market factors that have to do with resource scarcity, the central role of the price mechanism, and of the profit motive. Also, this group tends not to understand the strategic roles of business entrepreneurship, business partnership, business competitiveness and trade that characterize success in a private economy (Nwaokoro, 2017). These are the compelling issues that would warrant African Americans to have the strong incentives to step into the economic markets where the scarce resources are organized for purchase, and for sale to earn income and to learn entrepreneurship.

Poverty could relate to African American probability of death (Bata et al., 2020). A high probability of death would be expected in situations where poverty affects nutrition and healthcare. Poor individuals that do not have access to a frequent medical check-up may at critical situations end up in emergency medical rooms. These individuals could die before accessing the proper medical procedures. An extreme poverty could lead to serious adverse health conditions that could therefore elevate the probability of death. Poverty has been linked to serious illnesses such as stroke, heart ailments, and cancer among minority population (Lardner \& Smith, 2005; Owen \& Martinez, 2008; Riddell, 2011). Poverty therefore imposes a tremendous social cost and would elevate the effects of other societal adversities such as human discrimination, market and political disenfranchisement.

Without entrepreneurial culture, role of business partnership, and access to capital, African American got scattered in the population after the emancipation. As a result, the group has been unable to exercise self-employment to reduce their unemployment and poverty. The group, therefore, depends mostly on the majority for employment.

African American non-recessionary unemployment rate is unacceptable even in a growth economic period such as the period following the Great Recession (Note 1). In this period the respective rate is still higher than that of the white people. African American unemployment rate gets worse in a recessionary economy. The African American and white recessionary unemployment rates would imply that the African American is in a depression when the white is in a recession. Recessionary unemployment rate would perpetuate the non-ending African American poverty. Since African American derives most aggregated income from labor resource, high levels of unemployment and its duration would seriously impact among other things, the people's level of: consumer goods and services, education and training, healthcare, and savings. Each one of these would in turn hold back the group's economic development, would enlarge the poverty and perpetuate the purchasing power disparity. A long duration of increasing or unabated unemployment would magnify poverty to lead to a vicious cycle of poverty that may not be resolved by the price economy that harbors human discrimination.

With the limitations of African American market participation and poverty, the goal of this compelling exploratory study is to employ some critical, diverse, and compelling misery estimates of disparities that characterize and explain the persisting poverty among African American relative to that of the white particularly. These compelling estimates would among other persuasions suggest the need for African American to start having free market participation and to request for exogenous economic intervention to strongly minimize 
poverty. This study takes the strong stand that the contemporary market by itself will not resolve the enduring poverty without a deliberate action that will minimize the impact of the non- or latent -market economic participation that emanated from the two hundred years of slavery and two hundred years of segregation and Jim Crows. The following is the layout of the rest of the study. While section II highlights the critical disparity estimates, section III presents economic markets that African American may not have known. Section IV discusses poverty from the perspectives of the most critical disparity indices of labor discrimination and mass incarceration. The study's methodology, and conclusion and suggestions for future study are respectively handled in sections V and VI.

\section{The Disparity Estimates}

The disparity estimates in Table 1 below speak to the disparities and inequalities in the contemporary America.

Table 1. Estimates of proxies of poverty

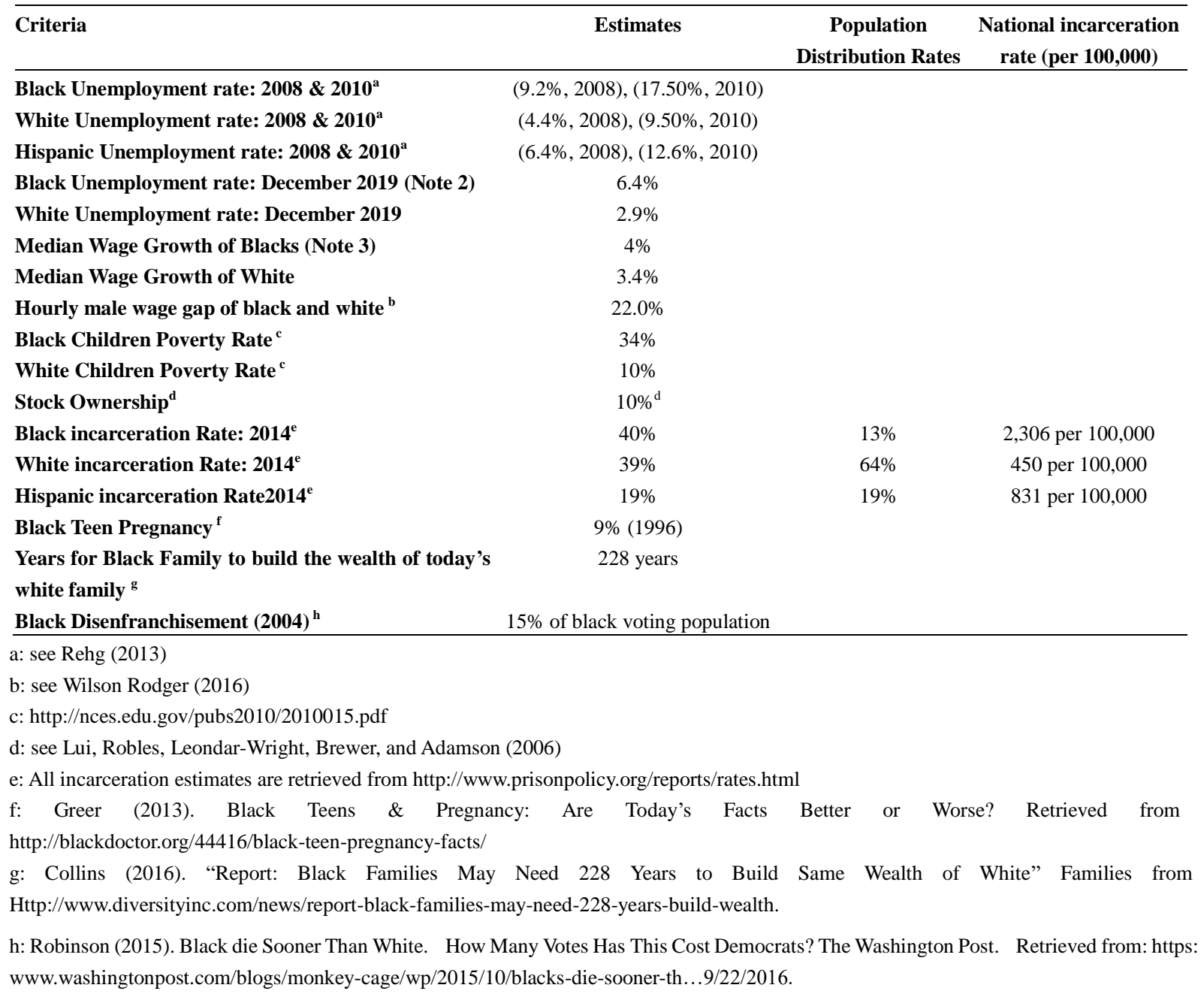

Reducing the misery estimates will require African Americans to embrace more economic markets; labor market particularly since they offer in this market, their most valuable resource being labor resource for earning income. The table presents that African American unemployment estimate is a bit more than twice of the whites. Comparing the unemployment estimates of African American and of white from the table would suggest that African American is in an economic depression when the white is in an economic recession. The disparity of the unemployment rates would also, tend to suggest that African Americans are not establishing businesses, have limited income multiplier, and are mostly dependent on the majority's establishments to earn labor income. Particularly, African Americans that are not or less educated would stand to disproportionately lose the most jobs during an economic recession. Plant automation could accelerate the job loss of this group especially during a recession. With labor discrimination and mass incarceration of the African American, the associated average 
disposable income of this group would not be substantial enough to warrant savings for investments.

Another compelling estimates from the table are those of the poverty that describe the black children's poverty rate as being a bit higher than thrice the comparable estimate for the white children. These children with the different poverty estimates may not have equal footings in the pursuit of excellence in education and in employment. A family that is unable to overcome an initial poverty could have children whose children would experience poverty and this situation can lead to a vicious cycle of poverty.

An incarceration rates show a substantial disparity with the proportion of African American incarcerated being by far higher than that of the majority. Income constraints, racial discrimination, free rider's effects, and faulty criminal justice system can lead to the disproportional group incarceration. Incarceration stigmatizes labor for discrimination and therefore would reduce the employment opportunities of the group with a higher percentage of the stigmatized labor.

A very low investment estimate of African American's stock ownership clearly implies that this group does not substantially operate in the financial market and in the acquisition of stocks to have part ownerships of corporations. Unawareness of the financial market and of trading in stocks, and limited disposable incomes mostly from the labor market could explain the African American's limited performances in the financial market and in stock trading. A high estimate of the teen pregnancy would elevate the poverty and illiteracy of the teen's families. The estimate could highlight kids' participation in hedonic activities. These conditions are capable of leading to a vicious cycle of poverty especially in a restricted environment.

An estimated long period (228 years) for black families to build the wealth that is comparable to the today's white wealth summarizes the cumulative effects of the economic disparities and inequalities in the contemporary America. Distributing resources by the price mechanism alone may not resolve this wealth gap. Some intensive and extensive exogenous market interventions tend to be expected to address this critical gap issue. African American disenfranchisement estimate also summarizes the inadequate African American participation in democracy and therefore in deciding the economic direction of their country. These summarized disparity estimates tend to inhibit the African American's human capital potentials and of market endowment.

\section{The Economic Markets That African American May Not Have Known}

We live in the world of scarcity of resources that shapes our rational decision choices. The scarce resources are traded in some economic markets. Resources are scarce because they have values and therefore can be purchased and sold. The quantity of the scarce resources that an individual could command depends mostly on the degree of the market foresight that the individual has. An individual's aggregate income is therefore positively related to the quantity of the owned scarce resources. Particularly and in the context of this research, the economic resources include labor, products, and finances and are respectively distributed in the labor, products, and bonds markets. Each of these resources has its specific price and income. Labor earns wage rate and its income, products gets the respective price, revenue, and profit income, and bonds attracts interest rate and interest income. How much of these resources that one owns will explain the person's disposable income and of the ability to operate in the bonds market and in the stock trading. African American's aggregate income and wealth will experience positive progressions depending on how much they are able to understand and to relate to the following narratives on the traits of the markets.

1) Labor market: This is the market where the labor service is distributed with the supplier's expectation of earning the wage rate and income. Also, this market is very important especially for those who lack the initiatives or entrepreneurship and the outlays to operate and to plan in the product, financial, and capital markets. In the labor market, labor is not a homogeneous or a common type. It is segregated according to the various levels of the labor quality possessed by the market participants' human capital. Human capital expresses the level of the combination of the productive traits--education, work experience, personal ability, technology, team work, and others that will enhance productivity. Enhancing productivity means small increases in productivity by a diminishing physical marginal product of labor being the demand for labor that is the basis for establishing the wage rate and the expected income earnings. Increase in technology, innovations, and trainings of labor can boost the productivity at the current level of the labor employment (a shift of the production function). The resultant increase in productivity from the effect of any of these productivity boosters would increase the wage rate and wage income.

Education that enhances human capital is an income equalizer and should be used to minimize African American unemployment (Ashenfelter, 1978; Becker, Murphy, \& Tamura, 1990; Welch, 1973). Particularly, those that do not have the capital and the entrepreneurship to participate in the product market as producers and in the bonds and capital markets as investors do need to have some preparation and commitment to enter the labor market. 
One of the ways to prepare actively for the labor market is the acquisition of the relevant education or skills needed in the field of employment that a labor is seeking. General education is acquired from the universities and colleges. General education tends to increase the circumstance-awareness of the educated minds and fosters the effective trainings of labor in various fields of employment. Acquisition of a higher education would increase the employability of the generally educated especially within a small segregated group of labor.

The less the competitiveness within a labor group than do others, the smaller is the group, and the quicker it is for the group participants to find gainful employment. With a severe competition within a group, the harder it could be to achieve a desired employment. This situation could warrant the group participants to have the need to acquire some additional market attributes to be individually differentiated to have a quick access to the desired employment. African Americans that are economically challenged and those who would not appreciate the long duration of acquiring a general education could opt for skill acquisitions for enhancing the application of their human capital in their specific labor market. It takes a relatively short period of time to have a skill acquisition. Whereby employment is accessed immediately after the short duration of training, the life cycle incomes of the skilled could approach or may even be greater than those of the generally educated. The cost of acquiring the skill-based education is usually lower compared to that for acquiring a general education. Technical colleges and businesses are generally liberal in providing grants and scholarships, and some other resources for market skill acquisitions.

2) Product and Service Markets: Here are markets where people exercise their levels of entrepreneurship based on their human capital (Lofstron \& Bates, 2007; Rosenzweig, 1990). The African American's presence in the product and service markets is highly limited and could be the major basis of the misery economic indices (Hotchkiss, 1993; Ucbasaran, Westhead, \& Wright, 2008). Most especially, for the long run minimization of the misery indices, African American needs to entrepreneurially explore the product and the service markets where profit incomes are earned. With a low capital outlay, market entry efforts could be directed to markets that are less concentrated. Market concentration describes market structures based on the competition and innovativeness in a market required for one to earn at least a competitive or an economic profit. Some specific product diversity values could aim to undermine competition by differentiating the attributes in new products or services or in the existing ones from the respective common ones.

An individual's limited capital outlay or of market foresight could encourage the formation of a business partnership. African American is yet to understand the vital importance of a business partnership. Business partnership brings individuals with similar market aspirations and visions, and it aggregates the individuals' limited outlays and their market attributes to underwrite a business' required initial outlay that is beyond the capacity of an individual partner or partners. With a business partnership, it could be possible to generate some economies of scale that could diminish the average cost of the operation. Diminishing the average cost of operation could lead to enhanced economies of scale, longevity, competitiveness, and profitability of the partnered business. Lack of personal trust could be an issue in a partnered entity.

The issue of the partners' integrity could be taken care of by drawing a charter that has clear expressions on the terms of the partnership. An issue of the unlimited liability will warrant that all the terms of the charter to be adequately and tactfully expressed. If there is an adequate trust base, all the partners may not need to be active in a partnered business. Those that may not be active known as "the sleeping or absentee partners" would only contribute funds to the business with the basic expectation of sharing from the business' profits relative to their contributions. The active partners would receive compensations for being active along with their shares of profits relative to their contributions. African American needs to understand that establishing a partnered business aims at the enhancement of the business' expected strategic economies of scale, competitiveness, profitability, and longevity. Avoidance of the unlimited liability would require the formation of a limited liability enterprises where the individuals' losses are limited only to the amounts contributed in the partnered business.

3) Financial and Capital Market: As in the product market, African Americans do not fare well in the financial market where an interest rate is established and have not recognize the importance of acquiring part ownerships of corporations by investing in stocks. From a national perspective, African American owns roughly $10 \%$ of all the bonds and stocks traded (Lui et al., 2006). One needs an income beyond the labor income to constitute income and wealth at high levels. It needs to be recalled that individual's income is constituted from the wage income, interest income, dividend, property-rent income, and from entrepreneurial income. Knowing and accepting to invest in the financial market and of acquiring part ownerships of corporations by investing in stocks will lead to an increasing future African American households' income.

Money invested along with all the capital gains if reinvested will be earning more income. Raising funds for 
investing in bonds and stocks is dependent on the ability to save by deferring some part of the current consumption to the future. For example, to raise investment funds overtime, one could save twenty-five cents out of every dollar that is earned by the saver. African Americans ought to be aware of the existence of the financial market and of investing in stocks even if there are no funds to cash on the current investment instruments. So, investments could be exercised when there are funds to relate to the associated opportunities.

Sources of Funds: Unless there is an inherited funds, both entrepreneurial and investment funds generally depend on savings out of a personal income derived mostly from wage, profit, rent, and interest, whichever that exists. Therefore, to increase wealth, there must be ability for, and commitment to saving. Other things being equal, to enhance a future wealth, the marginal propensity to save (MPS) described as the portion of income saved from a given level of income could increase as income increases. Individual's bank account with adequate compensating balance due to saving, could enhance the respective individual's ability to ask for a bank loan or an overdraft. Compensating balance is the bank required minimum balance for an account. A continuous maintenance of this balance in a long duration could be supportive when one is asking for a loan or an overdraft to start a new business or to enlarge an existing one.

Relatives and friends could be another source of entrepreneurial funds. Just as banks require a compensating balance for one to obtain personal loan or overdraft, relations and friends could ask how much the person seeking financial assistance has personally saved to be financially assisted. These requirements would highlight further, the importance of personal savings. After personal assistances from relations and friends, banks and small financial institutions would stand as the next sources of enterprising funds. Especially for the first request for a loan or an overdraft, an ability to maintain a compensating balance is one of the important ways to convince banks to release funds. Due to banks' enhanced economies of scale, interest rate is mostly cheaper in the banks than in the small financial companies. The scale provides banks with the ability to tolerate higher default risks from bigger lending than do the small financial companies that only provide small lending that the banks will not provide. For the small- and beginner-producers that could not access bank's funding, the initial requests for entrepreneurial loans may, first, be directed to the financial companies that tolerate small risk levels at high interest rates.

The high interest rates of the small financial companies tend to compensate and to correlate with the relatively high cost of operation and with the risks of default. As the entrepreneurial business becomes bigger, the entrepreneurial producer could seek for some partners to attract more funds, market attributes, and innovations to the proprietorial business. The problem with partnership is the unlimited liability. With unlimited liability, upon failure, a partner or other partners in the partnered business could assume the payment of debts that the other partners are unable to pay. Even private property could be used to settle partnership's debt. To avoid the problem of partnership's unlimited liability, a limited liability cooperation could be formed by selling shares of stocks to the public to generate substantial funds. With a limited liability, the investors would not lose beyond their contributions to the business and would not lose their private belongings to settle the business' debts. Summarily, an entrepreneur must initiate the expected market activities and a desire for an enhanced operational scale could encourage business partnership or cooperation to have an extra benefit by diminishing the issues of sole proprietorship and unlimited liability. The following section presents a narrative on some critical non-market events that could lead to a failure in the market efficiency on the side of the African American.

\section{Impacts of African American Labor Discrimination and Mass Incarceration on the Disparity Indices}

African American lives mostly in the southern U.S. that has about one-thirds of the U.S. population and shares about $40 \%$ of the national poverty (Riddell, 2011). Most especially in this region, both labor discrimination and mass incarceration of African American could be inhibiting the market understanding of this group. Labor discrimination based on race is the non- or limited- preference of members of some race for employment while preference is shown to members of another race for the same employment. Particularly, a group-based discrimination whose effects are carried over for years could intimidate and stigmatize the members of the group and are most likely to have an inadequate understanding of, and participation in the economic markets.

If a lot of the members of the discriminated group are rural and are used to program and subsistence incomes, it may be very difficult for these members to understand and to express economic events from the perspectives of a price-based economy. Even economic ratios could be very hard to interpret. So, the two hundred years of slavery, and the two hundred years of segregation and Jim Crows in the south would be expected to have adversely affected African American's application to and participation in the price-driven economy. Without exogenous economic interventions as witnessed in Europe after World War II, this adversity is likely to linger and to hinder the economic development of the African American. 
An incarceration record provides some misery estimate that describes African American as being heavily and disproportionately incarcerated. For example, Albany Metropolitan Statistical Area, Albany MSA of Georgia with African American majority has an incarceration rate of $0.25 \%$ that exceeds the state of Georgia's incarceration rate of about $0.21 \%$ (Georgia Department of Corrections, 2010). Also, Dougherty County that has the highest concentration of African American in the Albany MSA incarcerates three from everyone thousand people (Georgia Department of Corrections, 2010; Bello, 2008). The incarcerated are mostly: young, black and brown people, have productivity potentials, and come from mostly low socio- economic- and educationalbackgrounds. It is therefore clear that American correctional institutions' population is becoming browner and blacker. The incarcerated may not adequately understand the consequences of committing crimes that would adversely affect their market's potential earnings and the purchasing powers of their racial group.

A mass incarceration will interact with and aggravate the effects of the other disparity indices. The incarcerated or a felon may not earn according to the exhibited physical productivity of labor. Therefore, the conviction stigmatized labor is most likely to earn a wage that is below the market prevailing wage for the labor type and is likely to settle for jobs that are below the jobs that could be qualified for without an incarceration record. Even at the menial jobs, those with the incarceration record could easily be fired and may not vertically advance in an employment. So, with a conviction record, it becomes very hard for labor to find a gainful employment. Nwaokoro (2015) shows some correlation between income disparity, unemployment, and incarceration.

A labor that is severely discriminated due to incarceration could develop an incentive to withdraw from the labor market to the hedonic and criminal activities. Increasing utility or satisfaction especially from the hedonic activities could lead one to forget about the labor market where the real wealth is earned. An irrational behavior especially due to limited education and severe resource scarcity could magnify the adversity of labor discrimination and of incarceration. So, withdrawing from the labor market due to discrimination and incarceration could be quicker with the labor types that are less educated, are on menial jobs, and are experiencing increasing work disutility.

Summarily, the adverse effects of the estimates of the economic misery indices would interact with the effects of both labor discrimination and mass incarceration to lead to: high unemployment rate, low employment participation rate, high poverty rate, low average income, low income disparity ratio between African American and white. The exact effects from these undesirables may be difficult to ascertain due to limited continuity of the indices. However, at some micro levels such as the City of Albany, and Albany MSA, Georgia, with African American majority could serve as typical examples to characterize the severe effects of the misery indices. The city of Albany, Georgia with a high concentration of African American observes unemployment rates that are higher than the unemployment rates in the Albany MSA (Selig Center for Economic Growth, 2012). With the effect of a larger white population in the MSA than in the city specifically, the respective unemployment rates in the Albany MSA reduces. Also, the poverty rate in the inner section of the city is about $45 \%$ (Farr \& Slade 2008).

\section{Methodology}

The cited disparity estimates are mostly spot estimates that addressed some contemporary challenges like the ones that explain how much African American fared during the Great Recession. This is to say that the variables where the estimates are measured do not have continuous series. Particularly, the estimate of income variable is recorded on ten-year basis in the census record. Most of the variables are not disaggregated on racial demographic basis. These challenges inhibit the application of rigorous statistical procedures to address the significant African American misery indexes. Given these limitations, the study employs the basic ratio analysis to explain the contemporary African American limited market experience and persisting poverty. Therefore, this study summarizes the misery indexes in the vector of a ratio of the purchasing power of the African American to that of the white. This ratio is basically characterized by the lengthy time of African American: discrimination, and latent market entrepreneurship and partnership.

The purchasing power ratio is stated as:

Purchasing power disparity ratio $=\mathrm{f}($ African American purchasing power/white purchasing power $)$

Empirically, a purchasing power disparity ratio, 0.48 of African American incomes to white's is recorded in the Albany Metropolitan Statistical Area (Note 4). The ratio implies that an average African American earns roughly 48 cents for every $\$ 1$ earned by the average white. This insignificant purchasing power ratio explains the enduring African American poverty due to the long years of experiencing latent economic markets' participation. 


\section{Conclusion and Suggestion for Future Study}

This empirical study has succeeded in highlighting the disturbing disparity estimates of especially unemployment, poverty, and incarceration against African American in the contemporary America. These estimates from the respective indices seem to be enduring as African American does not adequately understand the intricacies of a market driven economy. The effects of the estimates are more severely felt especially during the African American economic depression. With the disparity estimates of the unemployment, it is apparent that the African American is in an economic depression when the white is in a recession. Mostly, an inadequate expression of: market attributes, business entrepreneurship and partnerships, and along with the effects of mass incarceration and of labor discrimination are identified as the root sources of the disparity estimates. Consequently, and seemingly, African American tends to self-select to exercise more initiative effort in faith-based and non-profit organizations.

Disparity of incarceration and the effects of labor discrimination continue to debase human capital in the contemporary America. The incarcerated labor or felons, and the discriminated labor would most likely not earn according to the dictates of the physical marginal product of labor and are likely to have stunned job advancements. Cumulatively, the effects of these estimates are elevated poverty that would describe the group's low aggregated income and purchasing power. These disparities stand to explain the African American's high poverty rate in the postindustrial competitive economy.

Understanding of the market economy is suggested to lead African Americans to alleviate the effects of the economic disparity estimates. To attract this understanding to achieve business competitiveness, the study narratives the importance of the idea of resource scarcity, of market concentration and competitiveness, and of the resource-distributive price mechanisms in the different economic markets of the U.S. economy. Particularly, business entrepreneurship and partnerships are identified as the critical economic routes for achieving enhanced and enduring African American economic growth and development especially within the group's immediate communities. These critical market factors would be expected to mitigate the adverse effects of the disparity estimates. With these outcomes, the business ownership and intra employment of the African American group would improve.

\section{References}

Ashenfelter, O. (1978). Estimating the effect of training program on earnings. Review of Economics and Statistics, 60(1), 47-57. https://doi.org/10.2307/1924332.

Bata, H., Earnell, S., \& Amaechi, N. (2020). The role of social security program for enhancing seniors' Longevity. Journal of Social Economics Research, 7(1), 1-11. https://doi.org/10.18488/journal.35.2020.71.1.11

Becker, G. S., Murphy, K. M., \& Tamura, R. (1990). Human capital, fertility, and economic growth. Journal of Political Economy, 98(5), 12-37. https://doi.org/10.1086/261723

Bello, M. (2008). Goal for Black America not met. USA Today, p. 6A.

Collins, C. (2016). Report: Black families may need 228 years to build same wealth of white. Retrieved from http://www.diversityinc.com/news/report-black-families-may-need-228-years-build-wealth

Farr, J. L., \& Sibyl, S. S. (2008). Albany, Georgia: The East Albany Neighborhood. Albany Georgia.

Georgia Department of Correction. (2010). Reports: 1990-2009 innate admission profile Annual statistics. Georgia Department of Corrections, Atlanta, GA. Retrieved from http://www.dcor.state.ga.us/Research/Monthly_Profile_all_inmates

Greer, W. (2013). Black teens \& pregnancy: Are today's facts better or worse? Retrieved from http://blackdoctor.org/44416/black-teen-pregnancy-facts/

Hotchkiss, L. (1993). Effects of training, occupation, and training-occupation match on wage. Journal Human Resources, 28(3), 482-496. https://doi.org/10.2307/146156

Lardner, J., \& David, S. A. (2005). Inequity Matters: The Growing Economic Divide in America and its Poisonous Consequences. New York: The New Press.

Lofstron, M., \& Bates, T. (2007). African Americans' pursuit of self-employment. Discussion Paper Series (Discussion Paper No. 3156). Institute for the Study of Labor. Bonn, Germany. Institute for the Study of Labor.

Lui, M., Robles, B., Leondar-Wright, B., Brewer, R., \& Adamson, R. (2006). The color of wealth. New York, NY: 
New York Press.

Nwaokoro, A. N. (2015). Purchasing power disparity faced by African Americans: Emphasis on Albany Metropolitan Statistical Area of Southwest Georgia. Journal of Poverty, 19(1), 20-40. https://doi.org/10.1080/10875549.2014.979459

Nwaokoro, A. N. (2017). Survey of free market principles for encouraging market: Participation of African American and the Economically Challenged. International Journal of Economics and Finance, 9(1), 130-144. https://doi.org/10.5539/ijef.v9n1p130

Nwaokoro, A. N., Marshall, C., \& Mittal, S. (2013). Exploratory study of the relationship between poverty and crimes in Albany/Dougherty, Georgia. Journal of Business \& Economics Research (JBER), 11(6), 277-292. https://doi.org/10.19030/jber.v11i6.7889

Owen, J., \& Martinez, J. (2008). Income inequality trend in Texas “Working Paper". Paper presented at 2008 Southwestern Economics Association, Denver, Colorado.

Rehg, M. (2013). The tea party: Pure ideology or economic dissatisfaction? Working Paper, The Ohio State University, Columbus, $\quad$ OH., $\quad$ pp. 1-69. $\quad$ Retrieved from http://kb.osu.edu/dspace/handle/1811/133/browser?value=Rehg\%2C+Marie\&type=author

Riddell. (2011). Economics: A toll for critical understanding society. Upper Saddle River, NJ: Pearson: Prentice Hall.

Robinson, E. (2015). Black die Sooner Than White. How Many Votes Has This Cost Democrats? The Washington Post. Retrieved from https://www.washingtonpost.com/blogs/monkey-cage/wp/2015/10/blacks-die-sooner-th...9/22/201

Rosenzweig, M. R. (1990). Population growth and human capital investments: Theory and evidence. Journal of Political Economy, 98(5), 38-65. https://doi.org/10.1086/261724

Samuelson, P. A., \& Nordhaus, W. D. (1998). Economics (6th ed.). New York, NY: McGraw-Hill/Irwin.

Selig Center for Economic Growth. (2012). The economic yearbook for Georgia's MSAs. Athens, GA: University of Georgia, Terry College of Business.

Smialek, J., \& Ben, C. (February 2020). Black Workers Wages' Are Finally Rising. The New York Times. Retrieved

from https://www.nytimes.com/2020/02/07/business/black-unemployment-wages.html?te=1\&nl=the-upshot\&em c=edit_up_20200210\&campaign_id=29\&instance_id=15880\&segment_id=21141\&user_id=421309b2bc11 732c5f04b819b26e2bb6\&regi_id=6912145620200210

U.S. Census Bureau. (2010). State and County QuickFacts. U.S. Department of Commerce. Retrieved from http://www.quickfacts.census.gov

Ucbasaran, D., Westhead, P., \& Wright, M. (2008). Opportunity identification and pursuit: Does an entrepreneur's human capital matter? Small Business Economics, 30(2), 153-173. https://doi.org/10.1007/s11187-006-9020-3

Welch, F. (1973). Black-White Differences in Return to Schooling. The American Economic Review, 63(5), 893-907.

Wilson, R. (2016). All incarceration estimates are. Retrieved from http://www.prisonpolicy.org/reports/rates.html

\section{Notes}

Note

https://www.nytimes.com/2020/02/07/business/black-unemployment-wages.html?te=1\&nl=the-upshot\&emc=edi t_up_20200210\&campaign_id=29\&instance_id $=15880 \&$ segment_id $=21141 \&$ user_id $=421309 \mathrm{~b} 2 \mathrm{bc} 11732 \mathrm{c} 5 \mathrm{f} 04 \mathrm{~b}$ 819b26e2bb6\&regi_id=6912145620200210

Note 2. See the black and white unemployment rates for December 2019: https://www.nytimes.com/2020/02/07/business/black-unemployment-wages.html?te=1\&nl=the-upshot\&emc=edi t_up_20200210\&campaign_id=29\&instance_id=15880\&segment_id=21141\&user_id=421309b2bc11732c5f04b 819b26e2bb6\&regi_id=6912145620200210

Note 3. Se the median wage growth of blacks and of white in December 2019: 
https://www.nytimes.com/2020/02/07/business/black-unemployment-wages.html?te=1\&nl=the-upshot\&emc=edi t_up_20200210\&campaign_id=29\&instance_id=15880\&segment_id=21141\&user_id=421309b2bc11732c5f04b 819b26e2bb6\&regi_id=6912145620200210

Note 4. The purchasing power variables for constructing the disparity purchasing power ratio in Albany Metropolitan Statistical Area is retrieved from the Selig Center of Economic Growth 2012

\section{Copyrights}

Copyright for this article is retained by the author(s), with first publication rights granted to the journal.

This is an open-access article distributed under the terms and conditions of the Creative Commons Attribution license (http://creativecommons.org/licenses/by/4.0/). 